\title{
The Use of a Selenium Rectifier Photo-electric Cell for Submarine Photometry.
}

\author{
By \\ H. H. Poole, Sc.D., \\ Registrar of the Royal Dublin Society, \\ and
}

W. R. G. Atkins, F.Inst.P., F.R.S.,

Head of the Department of General Physiology at the Plymouth Laboratory.

With 1 Figure in the Text.

Pното-eleCtric cells of the rectifier or "Blocking-layer" type possess such manifest attractions from the point of view of convenience that they have come into wide use for the measurement of illumination, especially for artificial light and for use as exposure meters. Several photometers making use either of the cuprous oxide cell of Lange (1930), or of the selenium cell of Bergmann (1931), or of that of Bernheim, the composition of which is as yet undisclosed, are now on the market for such purposes. Many, if not all, of these are graduated on the assumption that the current is related to the illumination by a rectilinear proportion; such a proportionality holds approximately for the relatively feeble illuminations met with indoors, when the galvanometers used are of low resistance. The cells have, however, in several instances been used for measuring daylight in the open without paying attention to the fact that, under such conditions, the illumination-current relationship is not rectilinear. We have already $(1933,1)$ gone into these and other precautions required in the use of rectifier cells, and have found $(1933,4)$ that for a Bergmann cell made by the Weston Electrical Instrument Co. the curvature of the illumination-current characteristic could be allowed for with sufficient accuracy by dividing the current in micro-amperes, $\mathrm{C}$, flowing through a 10-ohm galvanometer, by $1-0.003 \times \sqrt{ } \mathrm{C}$, the use of a divisor in place of a multiplying factor being more convenient, in this instance, for slide rule working; alternatively, a curve may be constructed from the formula to reproduce that found by experiment. Owing to its great sensitivity the cell, under opal-flashed glass, may give a current of over one milliampere at noon in the open late in January, when set horizontally. This must be divided by 0.905 to correct for curvature of characteristic, so that a current of 1.00 milliampere corresponds to a true illumination of $16 \cdot 0$ 
thousand metre candles; this would appear to be $14 \cdot 4$ if uncorrected. The figures are given on the " selenium, arc, scale," namely using a carbon arc to standardize the selenium cell. With summer illuminations of 50-100 thousand metre candles the difference between the true and the uncorrected illumination would be more serious.

It follows from this that, if such a rectifier cell be used for the permanent recording of daylight, corrections would need to be applied to the record charts. This effect might be greatly reduced (probably to negligible size) by mounting the cell so that it only received a small fraction of the light transmitted by a diffusing window and by then using a sensitive instrument to record the small currents obtained with this relatively feeble illumination.

The effect is generally negligible with vacuum emission cells, provided sufficient anode potential be applied to ensure saturation in the brightest light.

For measuring under-water illumination, rectifier cells were used by several workers almost simultaneously. We used a cuprous oxide cell $(1933,3)$ in the summer of 1932 , making use of a 10 -ohm galvanometer for measuring the current. The galvanometer was on land, the cell being carried by a diver. For use at sea it was proposed to use the potentiometer-telephone method to measure the open circuit voltage, the illumination-voltage relationship for which was found to show a very pronounced curvature. The cuprous oxide cell has since been abandoned as much inferior to the selenium rectifier.

Pearsall and Ullyott (1933) used a Bernheim cell in Lake Windermere, and give a comparison between its readings and those of a thin-film potassium on copper vacuum cell for February 8th. The Bernheim cell has a high sensitivity and a greater blue sensitivity than the selenium cell. A pointer galvanometer was found suitable for work from a small boat on the lake.

The most extensive series of measurements in the open sea with a rectifier cell were those carried out by Utterback and Boyle (1933) upon waters in and outside Puget Sound and up the coast towards Alaska; they worked in a small steamer, and used the Leeds and Northrup marine galvanometer; this is a mirror galvanometer with a specially robust suspension. To provide sufficient sensitivity a very powerful field is used, produced by an electro-magnet. The latter operates from a 6-volt circuit and takes half an ampere. Utterback found this quite satisfactory with the Bergmann-Weston cell, and worked down to $50 \mathrm{~m}$., using colour filters for the various regions of the spectrum and an ingenious electrically operated filter-changing mechanism.

In the Baltic Pettersson and Landberg (1934) used a selenium cell of the Bergmann type, constructed or modified by Lange, which, they 
state, has a maximum of sensitivity rather in the green than in the yellow orange as usual. This they used with a pointer galvanometer which worked well in their calm water. They found it necessary to use a screen to limit the illumination of their cell in strong light.

Our own work was carried out with two Bergmann-Weston selenium cells, one mounted on the deck-house roof, and the other in the small gunmetal case previously used for the cuprous oxide cell. With this we have made some preliminary measurements of the penetration of light of various colours into sea-water 1-2 miles south-east of Plymouth Breakwater.

\section{The Standardisation and Use of Rectifier Cells.}

We have dealt elsewhere with the optical conditions affecting a submerged photometer $(1933,2)$, and with the testing and behaviour of rectifier cells in bright light $(1933,1)$. It is only necessary to state here that the reading of a submerged photometer must be multiplied by 1.09 to correct for the nett effect of variations in internal and external reflections at the surface of the opal window, and that we must allow for the curvature of the current-illumination characteristic of the cell, which curvature becomes more pronounced as the resistance in series with the cell is increased. As high resistance also increases the error due to temperature variation of the cell, it is desirable to use a measuring instrument with the lowest possible resistance. The temperature variation error has been fully studied by Lange (1931).

For work on shore in comparatively bright light we have found a Cambridge Unipivot "Versatile" pointer galvanometer very suitable, as its resistance is only $10 \mathrm{ohms}$ and 1 scale division (readable to $0 \cdot 1$ ) corresponds to 2 micro amperes, i.e. to about 30 metre candles with the opal glass in position. For strong light a special shunt designed to maintain the effective resistance at 10 ohms $(1933,1$, p. 538) may be used.

For weak light, however (say below 500 m.c. or $0.5 \%$ of full noon sunlight), a more sensitive instrument is advantageous, and this will probably entail a higher resistance. This is not a serious drawback as the curvature of the characteristic is comparatively small in weak light, and can be corrected for if the requisite data for the given galvanometer resistance has been obtained by photometer bench tests $(1933,1)$ or by comparison with a vacuum emission cell $(1933,3)$.

We have not so far attempted to use a galvanometer at sea, as the comparatively small currents obtainable in deep or turbid water, especially with colour screens in use, would require a rather costly and sensitive instrument. We found it more convenient to employ our potentiometertelephone method $(1928,1933,2)$ which was available, rather than to 
attempt to fit up a system of gimbals sufficiently perfect to enable such a galvanometer to be used on board the trawler Salpa. We were not at the time aware of the existence of the special marine galvanometer. The only modification required in the apparatus was the reduction of the resistance through which the current from the cell passed, and across which the potential difference was measured by means of the potentiometer. In the measurements described below this resistance was made 10,100 or 200 ohms according to the brightness of the light to be measured, but subsequent experience has shown that values of 1000 or 10,000 ohms may be used in weak light, provided that suitable calibrations are effected. This means that for bright light with 10-ohm resistance one potentiometer scale division ( $10^{-4}$ volt) corresponds to about 150 m.c., while in weak light the sensitivity can be instantly increased as much as 400 times. There is evidently a limit to the gain of sensitivity obtainable in this way, as, even in very weak light, a large resistance reduces the current passing through; in fact the maximum P.D. available is the open circuit P.D. of the cell under the given illumination. This might be used, if desired, to measure very weak light, but this method would not increase the sensitivity greatly above that obtainable with $10,000 \mathrm{ohms}$ in circuit.

A curve for the open circuit P.D. of a cuprous oxide cell has already been given (1933, 3).

It is, however, doubtful whether the rectifier cells available at present can be used at considerable depths in the ocean, such as $180 \mathrm{~m}$. (Clarke, 1933), at which emission cells have been used. This doubt arises from the fact that though on open circuit the rectifier cell is rather more sensitive than the emission cell over 100,000 ohms, yet the latter may be used over 1 or 2 megohms. Furthermore, the potassium cell is most sensitive just where the water is most transparent, whereas the selenium cell has its maximum in the orange yellow.

For a typical Weston cell, with opal window, photometer bench tests have shown that the following resistances are convenient:

For currents up to $2.5 \mu$ a (c. 110 m.c.) 10,000 ohms, giving about $2.5 \times$ $10^{-4}$ volt per m.c.

For currents up to $50 \mu$ a (c. 1050 m.c.) 1,000 ohms, giving about $0 \cdot 5 \times$ $10^{-4}$ volt per m.c.

For currents up to $500 \mu$ a (c. 8500 m.c.) 100 ohms, giving about $0.06 \times$ $10^{-4}$ volt per m.c.

For currents over $500 \mu$ a (c. 8500 m.c.) 10 ohms, giving about $0 \cdot 006 \times$ $10^{-4}$ volt per m.c.

The calibration curve corresponding to the cell and the resistance must be used to find the value of the illumination.

For further work we have had constructed, by Messrs. Tinsley \& Co., a plug-in resistance set, so arranged that the potential difference measured 
can be across 10,100 or 1000 ohms according as a single plug is inserted. This aids rapidity of work, for while the air illumination is measured across 10 ohms the under-water illumination may be across 1000 ohms. Spare terminals and a spare plug-hole permit the use of $10,000 \mathrm{ohms}$ already in the potentiometer-telephone apparatus as part of the subdivided 100,000 ohm set.

The potentiometer method seems to be very suitable for work with rectifier cells. The absence of high potentials removes all insulation troubles, and the lowness of the resistance across which the P.D. is measured, as compared with the high value (100,000 ohms) generally needed with emission cells, renders the potentiometer balance very sharp. It could generally be set to within $0 \cdot 2$ scale division, viz. 20 microvolts, when the light was steady enough.

The surface illumination was measured by a cell mounted (under opal glass) on gimbals on the deck-house roof. This was the actual cell used in the laboratory and sky light measurements already recorded $(1933,1,4)$, so its characteristics for various series resistances were known. The cell used under water has not, as yet, been tested in this way, but for these preliminary measurements, under conditions in which great accuracy was hardly attainable, we may, without serious error, take its curvature corrections for various resistances to be the same as those for the " deck" cell. The two were almost the same in sensitivity.

The deck cell had been standardised against a carbon are by the method already described (1928, p. 460), and also against a standard vacuum lamp at a colour temperature $2360^{\circ} \mathrm{K}$.- the former gave $14.4 \mathrm{~m}$.c., and the latter $15 \cdot 1$ m.c. per $\mu$ a for the cell under opal glass exposed to weak diffuse light. The agreement shows the general similarity that this cell bears to the eye in its estimate of the relative brightness of sources of different colours. This is the first cell that we have found that can be standardised against a bare filament lamp and used to measure daylight without obtaining a scale of values utterly different from the visual one. This is a very great advantage, as the arc cannot be regarded as either a convenient or an accurate standard, though it possesses the advantage of readily providing high intensities. Some preliminary tests have indicated that winter daylight with low sun (February 15th, 1934, 15.30 G.M.T.), which was recorded as 15,850 m.c. by a vacuum potassium cell standardised against the arc, was measured as 12,400 m.c. by the Weston cell standardised against the standard filament lamp. Daylight measurements on what we may briefly call the "Selenium, $2360^{\circ}$, Scale " as used below, should, therefore, be about 78 per cent of the corresponding values on the "Potassium, Arc, Scale" which we have hitherto employed. The ratio of the two scales will, however, depend on the colour of the light, and hence on the relative proportion of direct sunlight, the selenium cell 
being relatively more sensitive to sunlight and the potassium cell to blue sky light.

\section{Submarine Measurements.}

One group of five series of readings was made a couple of miles south of Plymouth Breakwater on October 10th, 1933.

The usual procedure was adopted, sets of alternate readings of the deck and sea cells being made with the latter suspended from a spar projecting about $2 \cdot 2 \mathrm{~m}$. clear of the ship's counter, first with the cell about $1 \mathrm{~m}$. above the surface, where the shading due to the ship was small, and then at depths of 1, 5, 10 and 15 metres. Consistent readings could not be obtained at less than $1 \mathrm{~m}$., and the available depth did not allow of working below $15 \mathrm{~m}$., in fact on two occasions the photometer touched the bottom and had to be hauled up a metre or two.

Series were obtained with the cells covered only by opal glasses, and also with blue, green, yellow, and red, filters placed beneath the opal glasses of each photometer, so that the transmission of each filter was independent of the average obliquity of the incident light. The following are particulars of the conditions under which this group of series was obtained :--

Group W.1., including series W.1, W.1.B., W.1.G., W.1.Y., and W.1.R., October 10th, 1933. Drifting W. from position $\frac{1}{2}$ mile W. of Mewstone. Light variable, blue sky and white clouds, $\beta^{*}$ about 2.0 at 12.42 G.M.T. Wind E., moderate to fresh. Easterly swell. High water 6.51 G.M.T., tide flows to the W. until 2 hours after low water.

W.1. No colour filters. 11.21-12.01 G.M.T., commencing near Mewstone. Vertical surface illumination 45 to 71.5 thousands of metre candles (selenium, $2360^{\circ}$, scale). Touched bottom at $15 \mathrm{~m}$.

W.1.B. Chance's No. 7 blue filters, 13.05-13.25 G.M.T. (just after low water), commencing near Mewstone. Secchi disc visible to $9 \cdot 5 \mathrm{~m}$. at 13.11.

W.1.G. Corning "sextant green " filters, 13.41-13.59 G.M.T., commencing near Mewstone. Touched bottom at $15 \mathrm{~m}$.

W.1.Y. Sea cell, Chance's No. 4 orange filter. Deck cell Corning H.R. yellow, 14.9-14.50 G.M.T. Further W. than W.1.G.

W.1.R. Schott R.G.1 red filters, 15.05-15.21 G.M.T. Wind lighter. Further W. than W.1.Y.

The results are plotted in the figure on a logarithmic scale as percentages of the vertical surface illumination of the same colour. It will be noted that they all indicate a somewhat large surface loss, which is not unusual with strong winds. Surprisingly clear water seems to have been

* As before $\beta$ denotes the ratio of light from sun plus sky to that from sky alone, receiving surface being set horizontally. 
encountered during the 5-m. readings of series W.1.B., otherwise the results are in accordance with what we should expect for inshore waters, where green light is generally found to penetrate best $(1933,2)$. It is worth noting that the vertical absorption coefficient $\mu_{\mathrm{v}}$ for series W.1.B,

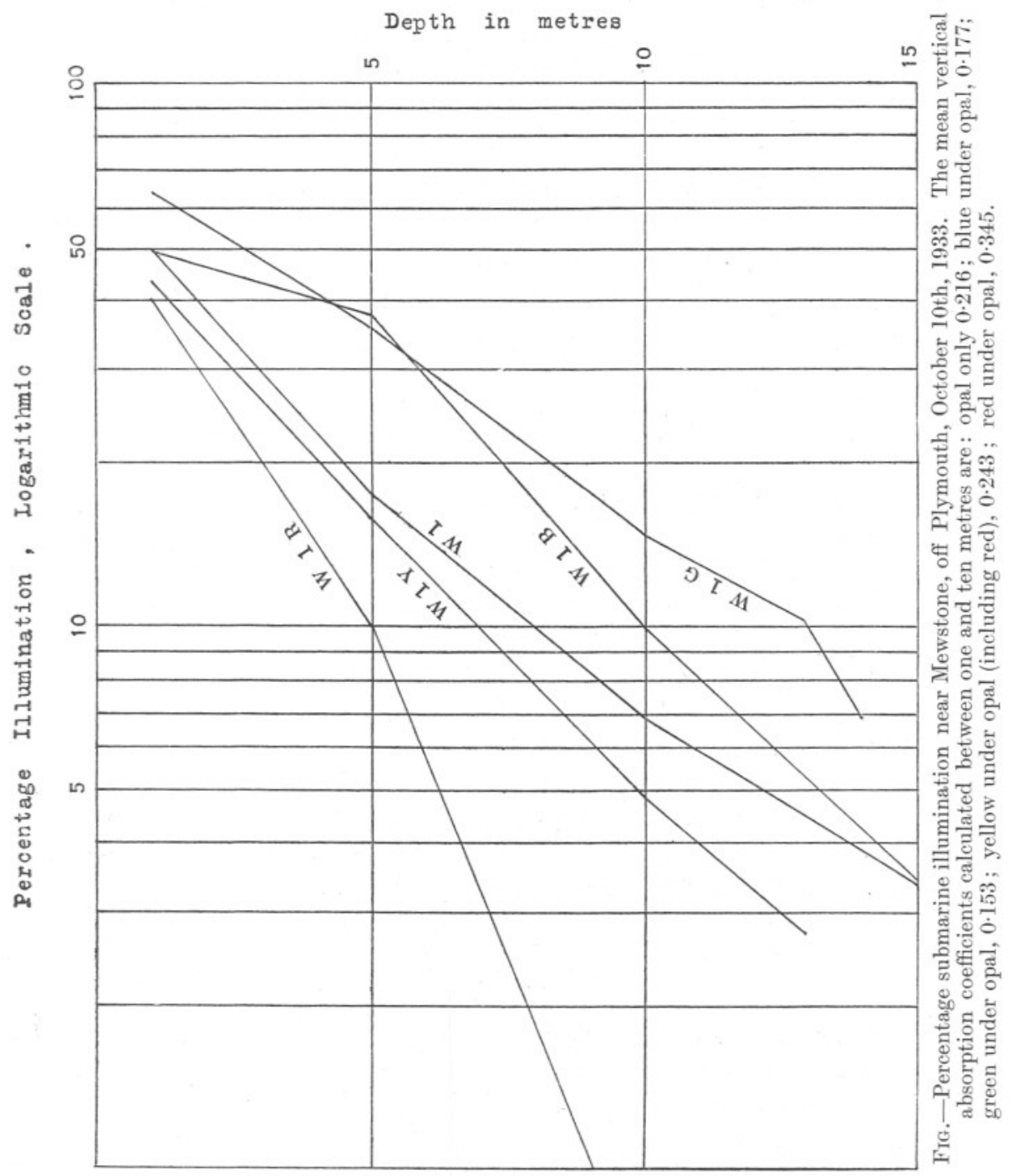

(1-10 m.) viz. $0 \cdot 177$, agrees almost perfectly with the value $0 \cdot 179$ found by the rough rule $\mu_{\mathrm{v}}=1 \cdot 7 / \mathrm{D}$ which we have previously found applicable as a correlation between $\mu_{\mathrm{v}}$ for blue light and $\mathrm{D}$, the maximum depth of visibility of the Secchi disc. 
The results shown in the figure agree well with certain of our previous determinations on inshore waters in 1931, carried out at about 1-2 miles off the shore in Whitsand Bay, to the west of Plymouth Sound. These were made using an emission cell, thin-film caesium type CMV6 with colour filters The table shows that the water was slightly clearer for the August 1931 measurements. The filters were the same for the red and green in each year, and very similar in the other cases.

\section{TABLE I.}

Showing the Depths in Metres at which the Air Illumination is Reduced, in Water, to 10 Per Cent. The series numbers REFER TO THE 1931 measurements ONLY, SINCE ALL THE 1933 RESULTS ARE GIVEN.

$\begin{array}{lrcccc}\text { Filter. } & \text { Blue. } & \text { Green. } & \text { Yellow. } & \text { Red. } & \text { "White." } \\ \text { Series } & 80 \mathrm{~B} & 72 \mathrm{G} & 71 \mathrm{Y} & 74 \mathrm{R} & 68 \mathrm{H} \\ 1931 & 10 \cdot 6 & 14 \cdot 6 & 8 \cdot 0 & 5 \cdot 0 & 7 \cdot 4 \\ 1933 & 9 \cdot 9 & 13 \cdot 0 & 7 \cdot 0 & 5 \cdot 0 & 7 \cdot 9\end{array}$

Only in the "white" column does the water appear clearer in 1933 than in 1931. This column for 1931 represents the thin-film caesium cell, with a heat-absorbing filter, light green in tint ; this renders its sensitivity nearly uniform over the visible spectrum and absorbs the near infra-red to which this cell is very sensitive. The figures indicate, however, that the selenium cell, which has a maximum sensitivity about $590 \mathrm{~m} \mu$, is relatively slightly more sensitive to green light, which penetrates best, than the CMV6 cell with heat-absorbing filter.

The values of percentage illumination given in the table are actual values, read off from the graphs, but as measures of clearness of the water the comparison is not exact, since the surface losses were not the same on the different dates. The general agreement is, however, quite evident.

\section{SUMMARY.}

1. Measurements of the penetration of light of various colours into the sea were carried out by means of a selenium rectifier cell. The mean vertical absorption coefficients were: for blue, 0.177 ; green, 0.153 ; "white," viz. no filter, $0 \cdot 216$; yellow, $0 \cdot 243$; red, $0 \cdot 345$. The results accord well with those obtained under similar conditions with emission cells and show that, for water a couple of miles offshore, green light penetrates best.

2. The current was measured using the potentiometer-telephone method as for emission cells, but determining the drop in potential across 
a low resistance, 10,100 , or 1000 ohms. The motion of the ship was too violent to permit of the use of any available galvanometer of adequate sensitivity.

3. Rectifier cells are more convenient to use than emission cells, as the currents to be measured are much larger and the absence of high potentials greatly simplifies all insulation problems. On the other hand the curvature of the illumination-current relation involves additional labour in standardizing and in calculating results.

\section{REFERENCES.}

Atkins, W. R. G., and Poole, H. H. 1933, 2. The photo-electric measurement of the penetration of light of various wave-lengths into the sea and the physiological bearing of the results. Phil. Trans. Roy. Soc. London, B., Vol. 222, pp. 129-164.

— 1933, 3. The use of cuprous oxide and other rectifier photo cells in submarine photometry. Journ. Mar. Biol. Assoc., N.S., Vol. XIX, pp. $67-72$.

Bergmann, L. 1931. Über eine neue Selen-Sperrschicht-Photozelle. Physik. Zeitschr., Vol. 32, pp. 286-288.

Clarke, G. L. 1933. Observations on the penetration of daylight into Mid-Atlantic and coastal waters. Biol. Bull., Vol. 65 (No. 2), pp. 317 337 .

Lange, B. 1930. Über eine neue Art von Photozellen. Physik. Zeitschr., Vol. 31, pp. 139-140.

— 1931. Über die Temperaturabhängigheit des SperrschichtPhotoeffektes. Loc. cit., Vol. 32, pp. 850-856.

Pearsall, W. H., and Ullyott, P. 1933. Measurement of light for biological purposes. Nature, Vol. 131, p. 694.

Pettersson, H., and Landberg, S. 1934. Submarine daylight. Med. f. Göteborgs Högskolas Oceanografiska Inst., No. 6, p. 13 (Göt. Kungl. Vetenskaps—och Vitterhets—Samhälles Handl. Ser. B, Vol. 3, No. 7).

Pettersson, H. 1934. A transparency meter for sea-water. Loc. cit., No. 7, p. 17.

Poole, H. H., and Atkins, W. R. G. 1928. Further photo-electric measurements of the penetration of light into sea-water. Journ. Mar. Biol. Assoc., N.S., Vol. XV, pp. 455-483. 
Poole, H. H., And Atkins, W. R. G. 1933, 1. Experiments on the suitability of some rectifier photo cells for the measurement of daylight. Sci. Proc. Roy. Dublin Soc., Vol. 20 (No. 36), pp. 537-546.

— 1933, 4. Some measurements of the brightness of various parts of the sky by means of a rectifier photo-electric cell. Loc. cit., Vol. 21 (No. 1), pp. 1-8.

Utterback, C. L., and the late Boyle, J. Watson. 1933. Light penetration in the waters of the San Juan Archipelago. J. Optical Soc. Amer., Vol. 23, No. 10, p. 10.

UtTerback, C. L. 1933. Light penetration in the waters of Southern Alaska. Loc. cit., No. 10, p. 5. 